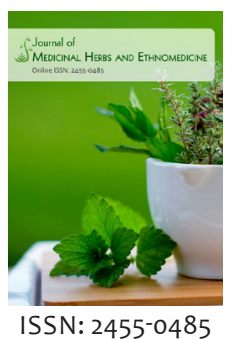

Received: January 04, 2019 Accepted: March 15, 2019 Published: March 21, 2019

*Corresponding author: Saban Keskïn Email: sabankeskin61@ hotmail.com

\section{Ultrasound assisted extraction of pectin from Trachystemon orientalis $\mathrm{L}$.}

\author{
Şaban Keskin ${ }^{1 *}$, Merve Keskinn², Sevgi Kolayli \\ ${ }^{1}$ Department of Chemistry, Faculty of Science and Literature, Bilecik Şeyh Edebali University, Bilecik, Turkey, \\ ${ }^{2}$ Department of Chemistry, Institute of Natural Science, Karadeniz Technical University, Trabzon, Turkey, \\ ${ }^{3}$ Department of Chemistry, Faculty of Science, Karadeniz Technical University, Trabzon, Turkey
}

\begin{abstract}
Pectin, a natural bio polymer, has wide range of applications in different fields because of its gelling, stabilizing and emulsifying ability as food additive/preservative and drug carrier etc. Main objective of this study was to describe the extraction of pectin for the first time from Trachystemon orientalis L., a medicinal plant grown in black sea region of Turkey. Pectin was extracted from the plant by ultrasound assisted acid hydrolysis method. Obtained pectin was characterized by using ATR-FT-IR and TGA methods. It was observed that the plant contained $2.5 \%$ pectin $(0.25 \mathrm{~g}$ pectin/ per $10 \mathrm{~g}$ dried sample). Obtained pectin was labeled as High Methyl esterified Pectin (HMP) as its methoxyl- content was found to be $80 \%$ by using titrimetric method. ATR-FT-IR and TGA images were obtained as well. It can be concluded that Trachystemon orientalis L. could be a new source for pectin production for food and pharmaceutical industries.
\end{abstract}

KEY WORDS: Pectin, Trachystemon orientalis L, SEM, FT-IR, TGA

\section{INTRODUCTION}

Trachystemon orientalis (L.) G. Don., a member of Boraginaceae, is a long term herbaceous plant. It is the only species in the genus Trachystemon D. Don in Turkey and distributed in various habitats in Black sea region. This plant is also native and distributed through the Europe as well. It is $30-40 \mathrm{~cm}$ in length with a rhizome. It has a broad leaf and red-blue flowers. The plant has medicinal importance because of its bioactive contents such as essential oils, tannins, resin, mucilage and nitrates. It has diuretic, febrifuge, antimicrobial and antifungal effects [1,2]. The rhizomes, leaves, petioles and flowering branches are separately consumed as vegetable through the locals of Black Sea region.

Pectin is a hetero polysaccharide and it occurs at cell walls of all land plants $[3,4]$. Pectin is used as food ingredient especially gelling and stabilizing agent in jams [4]. Pectin could be extracted by using different methods. Acid hydrolysis method, extraction by enzymes, extraction by microwave and extraction by ultrasound are the methods used alone or in a combination [5]. Recently, some properties of Trachystemon orientalis were reported in literature such as polyphenol oxidase purification [6], nutritional and seed properties [7], antimicrobial activity [8], its traditional medicinal use [9], antifungal activity [10] and antioxidant activity [11]. The addition of T. orientalis L. into Tarhana, a traditional Turkish fermented soup, to increase the dietary fiber content was also reported [12]. Main objective of this study was to describe the extraction of pectin for the first time from Trachystemon orientalis $\mathrm{L}$. and to characterize obtained pectin. It was also discussed that whether T. orientalis could be a new source for pectin production.

\section{MATERIAL AND METHOD}

\section{Materials}

Trachystemon orientalis L. samples were collected freshly from Kırankaş, a village of Trabzon city, during the May and Jun in 2016. Sulfuric acid, hydrochloric acid, citric acid, acetic acid, calcium chloride di-hydrate, ethanol, sodium hydroxide were purchased from sigma Aldrich. All solutions were prepared with deionized water.

\section{Extraction of Pectin}

Trachystemon orientalis L. was collected around Trabzon city of Turkey in early summer season, between May and Jun, of 2016. $100 \mathrm{~g}$ of Trachystemon orientalis was boiled in $250 \mathrm{~mL}$ water for about 15 minutes in order to remove low molecular weight carbohydrates, organic acids, coloring matter and minerals. After that this mixture was filtered. Bagasse was extracted with acidified water with different acids as $\mathrm{HCl}, \mathrm{H}_{2} \mathrm{SO}_{4}, \mathrm{CH}_{3} \mathrm{COOH}$, and citric acid for about $\mathrm{l} \mathrm{h}$ with condenser at $85^{\circ} \mathrm{C}$. The $\mathrm{pH}$

Copyright: () The authors. This article is open access and licensed under the terms of the Creative Commons Attribution License (http://creativecommons.org/licenses/by/4.0/) which permits unrestricted, use, distribution and reproduction in any medium, or format for any purpose, even commercially provided the work is properly cited. Attribution - You must give appropriate credit, provide a link to the license, and indicate if changes were made. 
of acidified water was set to 2.00 for $\mathrm{HCl}$ and $\mathrm{H}_{2} \mathrm{SO}_{4}$ and 2.50 for acetic acid and citric acid. Extraction was continued for 30 min more at $85^{\circ} \mathrm{C}$ with ultra-sonication by using wise clean ultrasonic bath (WUC-AlOH) only for $\mathrm{H}_{2} \mathrm{SO}_{4}$ extraction. After extraction, the mixture was filtered and cooled down to room temperature. After cooling down, filtrate was mixed 1:1 absolute ethanol and pectin was precipitated. This mixture was waited at $4^{\circ} \mathrm{C}$ and pectin was filtered and washed three times with $65 \%$ and finally with absolute ethanol. Obtained pectin was dried at $65^{\circ} \mathrm{C}$ in a vacuum oven, grounded and stored at room temperature for further analyses.

\section{Characterization of the Pectin}

In order to characterize pectin, \% esterification degree, thermal behavior of pectin, ATR-FT-IR spectrum and galacturonic acid content were determined.

\section{Determination of methyl esterification degree (\%)}

Methyl esterification degree was determined by titrimetric method with phenolphthalein as indicator. $0.1 \mathrm{~g}$ of pectin obtained with sulfuric acid was dissolved in $10 \mathrm{~mL}$ distilled water and titrated by $0.1 \mathrm{~N} \mathrm{NaOH}$ and end point consumption $\left(\mathrm{V}_{1}\right)$ was recorded. After that $10 \mathrm{~mL}$ of $0.1 \mathrm{~N} \mathrm{NaOH}$ was added into this solution to de-esterify pectin. Obtained solution was neutralized by the addition of equal volume of $0.1 \mathrm{~N} \mathrm{HCl}$. This solution was further titrated by $0.1 \mathrm{~N} \mathrm{NaOH}$ and end point consumption $\left(\mathrm{V}_{2}\right)$ was recorded. Esterification degree $(\%)$ was calculated with the given formula.

$\operatorname{ED}(\%)=\left(V_{2} / V_{1}+V_{2}\right) * 100$

where

$V_{1}$ is the first end point consumption $(\mathrm{mL})$ and $V_{2}$ is the final titration end point consumption (mL) $[13,14]$.

\section{Determination of galacturonic acid content}

Galacturonic acid (GalA) content was measured spectrophotometrically by using Folin-Ciocalteau reagent. Sample was prepared to GalA analysis by hydrolyzing obtained pectin with concentrated $\mathrm{H}_{2} \mathrm{SO}_{4}$ for $2 \mathrm{~h}$ boiling. Briefly, a buffered copper solution was prepared as described by Anthon \& Barrett [15]. For the assay equal volumes $(0.1 \mathrm{~mL})$ of standard Gal A solution in different concentration and the sample were mixed with this solution separately in test tubes. Then the tubes are covered with aluminum folio and placed in boiling water at $100^{\circ} \mathrm{C}$ for $40 \mathrm{~min}$. After removing the samples from the heat bath 40-fold diluted Folin-Ciocalteau reagent was immediately added. Absorbance of the formed colored product was measured at $750 \mathrm{~nm}$ against a blank. Gal A content was calculated from the linear standard graph.

\section{Determination of thermal behavior of pectin}

Thermal behavior of pectin was determined by using SII TG/ DTA 7200 exstar thermal analysis instrument. $10 \mathrm{mg}$ of pectin was weighed and put in measure range. Analysis was carried out in a nitrogen atmosphere with $10^{\circ} \mathrm{C}$ temperature increment in $1 \mathrm{~min}$ in the range of $50-600^{\circ} \mathrm{C}$.

\section{Analyzing of pectin with ATR-FT-IR}

ATR-FT-IR of pectin and pectin nanobeads was carried out by using Perkin Elmer, FT-IR 2000 instrument. For obtaining the spectrum, small amount of obtained pectin was put in the instrument and spectrum was obtained at a range of $4000-650 \mathrm{~cm}^{-1}$.

\section{RESULTS AND DISCUSSION}

\section{Pectin Extraction}

In order to determine the effect of extraction procedure and extraction conditions on pectin recovery, extractions were carried out by using conventional acid hydrolysis and ultrasound assisted acid hydrolysis methods. $\mathrm{H}_{2} \mathrm{SO}_{4}$ was found to be the best acid for pectin extraction from T. orientalis among the tested ones. It was found as expected that ultrasound assisted extraction gave better pectin recovery. Results were summarized in Table 1. Although there are several factors like, $\mathrm{pH}$, extraction time, extraction temperature, type of acid etc. effecting pectin recovery, our aim was not to optimize the conditions since this was a pilot study of describing the extraction of pectin from T. orientalis.

It is obvious that more study should be carried out for optimization of pectin extraction from T. orientalis on the bases of optimization parameters. In the current time the market is dominated from the pectins obtained from citrus wastes and apple pomace and produced pectins is mostly used in food industry [16]. Recently several agro by products or plant species have been searched for their pectins to offer the market new sources because pectin is gaining more value in different fields like special food formulation, pharmaceuticals and targeted drug formulations [17]. In this approach describing new pectin sources has a great importance. As mentioned before T. orientalis is a wild growing plant at Black Sea region in Turkey and Europe. When considered the annual production amount of the plant, T. orientalis could be a new source for production of high methoxylated pectin.

\section{Characterization of Obtained Pectin}

For the characterization of pectin obtained from T. orientalis L. degree of esterification, galacturonic acid content, thermal behavior and FT-IR spectrum was studied.

Table 1: Pectin recovery under different extraction conditions Pectin Recovery (\%)

\begin{tabular}{lcc}
\hline Acid Used & CAH & UACAH \\
\hline Sulphuric Acid & 2.13 & 2.54 \\
Hydrochloric Acid & 1.88 & $\mathrm{Nt}$ \\
Acetic Acid & 1.76 & $\mathrm{Nt}$ \\
Citric Acid & 1.92 & $\mathrm{Nt}$ \\
\hline
\end{tabular}

Results represent the pectin recovery as g pectin from $100 \mathrm{~g}$ fresh sample. $\mathrm{CAH}$ : Conventional Acid Hydrolysis, UACAH: Ultrasound Assisted Conventional Acid Hydrolysis, nt: Not Tested 
Keskin, et al.

\section{Determination of Esterification Degree\%}

Esterification degree of obtained pectin was determined by using a titrimetric method. Obtained pectin could be labeled as high methyl esterified pectin since the pectin contained $80 \%$ methyl esterification degree. The degree of methyl esterification (DM) is the crucial factor in determining the usage area of a pectin since its biological activity, gelling ability and solubility are characterized by the DM [18]. Obtained pectin could be used as food additive for its high gelling capacity. Obtained pectin could be used in special food formulation as a high-methyl esterified pectin was a good cholesterol-lowering agent.

\section{Determination of galacturonic acid content}

Obtained pectin contained $71 \% \mathrm{GalA}$ content. It is well known that GalA content is an important parameter for a pectin as it is the repeated unit of homo galacturonan, the most abundant of the three polymers. Functional properties of a pectin mostly depends on the GalA content and its methyl esterification degrees. It was reported that galacturonic acid content of food grade pectin should not be less than $65 \%$ for food additive.

\section{Determination of thermal behavior of pectin}

Obtained pectin was dried at $65^{\circ} \mathrm{C}$ in a vacuum oven and examined by using SII TG/DTA 7200 exstar thermal analysis instrument. Achieved curve was represented in Figure 1. It is clear from the figure that at temperatures between $50-180^{\circ} \mathrm{C}$, water was removed from the surface and between molecules, indicating that obtained pectin contains about $18 \%$ moisture. Between $190-400^{\circ} \mathrm{C}$ the polymeric chain was disintegrated and rapid pyrolytic combustion occurred, between $400-600^{\circ} \mathrm{C}$, the remaining charred structure was burned. The residue was defined as ash content of pectin about $16.45 \%$. Similar ash content was reported in literature [5].

Fourier transform infrared spectrometry (FT-IR)

Obtained pectin was analyzed by using ATR-FT-IR technique. Peaks were recorded and represented in Figure 2. Some prominent bands could be summarized in six group. First

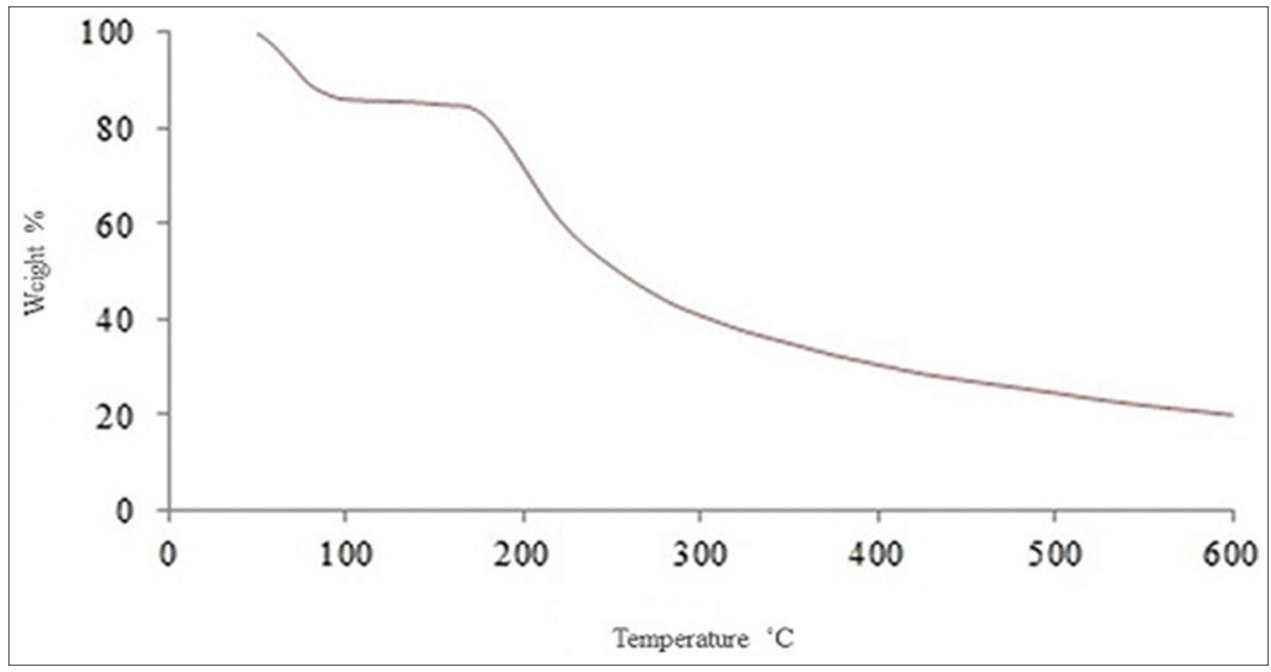

Figure 1: Thermal gravimetric analyses of obtained pectin

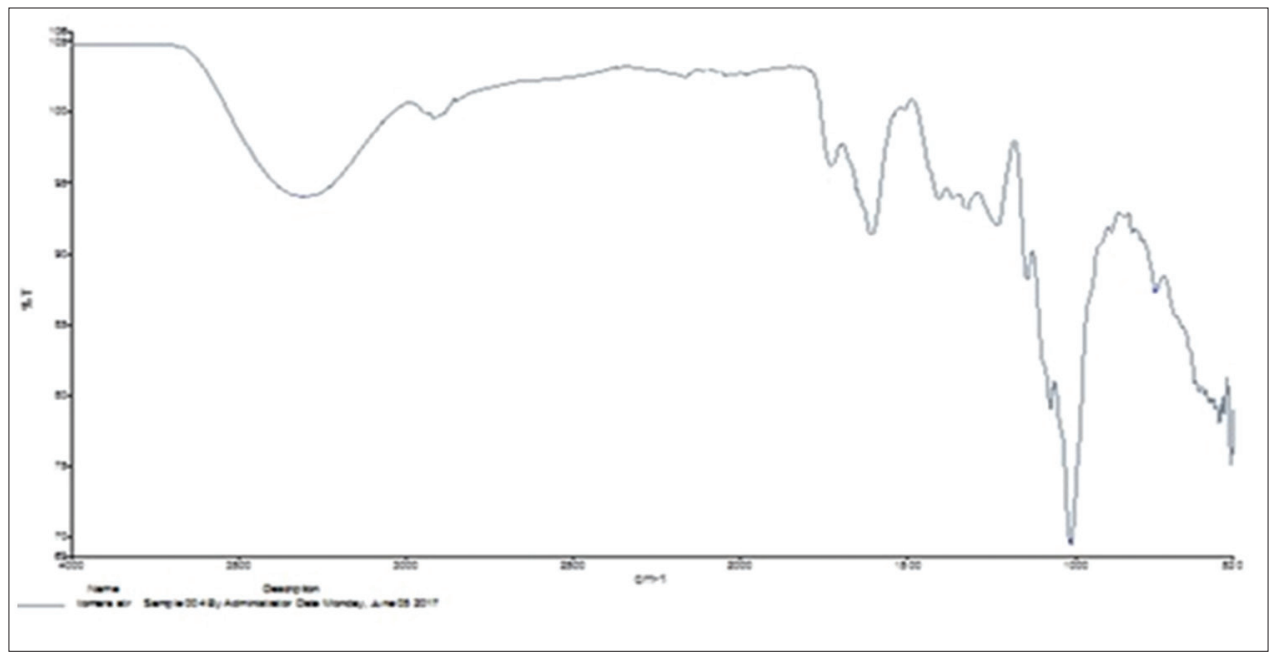

Figure 2: ATR-FT-IR Spectrum of obtained pectin 
one is the band occurred around $3500 \mathrm{~cm}^{-1}$ representing the uncommitted $\mathrm{O}-\mathrm{H}$ peaks either from the hydroxyl group found in galacturonic acid or water. The band occurred around $2900 \mathrm{~cm}^{-1}$ could be explained by C-H stretching vibration. Specific bands representing the methyl ester group in pectin were recorded around $1700 \mathrm{~cm}^{-1}$ related to $\mathrm{C}=\mathrm{O}$ stretching. Also the C-O-C stretching modes of the glycosidic linkages in pectin were recorded around $1100 \mathrm{~cm}^{-1}$. Bands occurred around $1000 \mathrm{~cm}^{-1}$ could be explained by the C-O and C-C stretching modes and bands recorded around 990 could be related to $\beta$, 1-6 glucans in pectins [19, 20].

\section{CONCLUSION}

The usage area of the pectin has increased in recent years. It is not only used in food formulations but also in medicinal and pharmaceutical field since its mucoadhesive and gelling abilities. These different field application requires different types of pectin in standardized grade and quality. In the present study, extraction of pectin from T. orientalis for the first time was reported. Some of its chemical characterization were reported as well. Obtained pectin has interesting chemical future and could be a new source for pectin production. Further studies should be carried out for standardized production of pectin from T. orientalis and its potential usage in pharmaceutical field.

\section{CONFLICT OF INTEREST}

There is no conflict of interest between authors.

\section{REFERENCES}

1. Baytop T. Türkçe Bitki Adları Sözlü口ü. Ankara: Atatürk Kültür, Dil ve Tarih Yüksek Kurumu Türk Dil Kurumu Yayınları: 1994;578.

2. Akçin, Ö.E., Kandemir, N., Akçin, Y. A morphological and anatomical study on a medicinal and edible plant Trachystemon orientalis (L.) G.Don (Boraginaceae) in the Black Sea Region. Turkish Journal of Botany. 2004;28:435-442

3. Petrova I, Petkova B, Kyobashieva B, Denev B, Simitchiev C, Todorova B, Dencheva B. Isolation of pectic polysaccharides from Celery (Apium graveolens var. rapaceum D. C.) and their application in food emulsions. Turkish Journal of Agricultural and Natural Sciences Special Issue: 2014;1818-1824.

4. Liu L, Cao J, Huang J, Cai Y, Yao J. Extraction of pectins with different degrees of esterification from mulberry branch bark. Bioresource Technology. 2010;101:3268-3273.

5. Bayar N, Bouallegue T, Achour M, Kriaa M, Bougatef A, Kammoun R. Ultrasonic extraction of pectin from Opuntia ficus indica cladodes after mucilage removal: Optimization of experimental conditions and evaluation of chemical and functional properties. Food Chemistry. 2017;235:275-82.

6. Alici EH, Arabaci G. Purification of polyphenol oxidase from borage (Trachystemon orientalis L.) by using three-phase partitioning and investigation of kinetic properties. Int $\mathrm{J}$ Biol Macromol. 2016;93:1051-1056.

7. Kibar B, Kibar H. Determination of the nutritional and seed properties of some wild edible plants consumed as vegetable in the Middle Black Sea Region of Turkey. South African Journal of Botany. 2017; 108:117-25

8. Uzun E, Sariyar G, Adsersen A, Karakoc B, Gulten Ö, Oktayoglu E, Pirildar S. Traditional medicine in Sakarya province (Turkey) and antimicrobial activities of selected species. Journal of Ethnopharmacology. 2004;95:287-296.

9. Polat R, Cakilcioglu U, Kaltalioğlu K, Ulusan MD, Türkmen Z. An ethnobotanical study on medicinal plants in Espiye and its surrounding (Giresun-Turkey). Journal of Ethnopharmacology. 2015:163:1-11.

10. Onaran A, Yılar M. Antifungal Activity of Trachystemon orientalis L. Aqueous Extracts against Plant Pathogens. Journal of Food, Agriculture \& Environment. 2012;10(3\&4):287-291.

11. Ayvaz CM. Antioxidant activity of Trachystemon orientalis (L.) G. Don (Borage) grown and eaten as food in Ordu, Turkey. Herba Polonica, 2015;61(4):40-51.

12. Koca AF, Koca I, Anil M, Hasbay I, Yilmaz VA. Physical, rheological and sensory properties of Tarhana prepared with two wild edible plants (Trachystemon orientalis (L.) G. Don) and (Portulaca oleracea L.) Journal of Food Process Technology. 2015;6:443-450.

13. Filippov MP., Shkolenko GA., Kohn R. Determination of the esterification degree of the pectin of different origin and composition by the method of infrared spectroscopy, Chem. Zvesti, 1978;32(2):218-222

14. Tiwari AK, Saha SN, Yadav VP, Upadhyay UK, Katiyar D, Mishra T. Extraction and characterization of pectin from orange peels. International Journal of Biotechnology and Biochemistry. 2017;13(1):39-47.

15. Anthon GE and Barrett DM. Combined enzymatic and colorimetric method for determining the uronic acid and methylester content of pectin: Application to tomato products. Food Chemistry. 2008;110:239-247.

16. Willats WGT, Knox JP, Mikkelsen JD. Pectin: New insights into an old polymer are starting to gel. Trends in Food Science and Technology. 2006; 17:97-104

17. Srivastava P and Malviya R. Sources of pectin, extraction and its applications in pharmaceutical industry, An overview. Indian Journal of Natural Product and Resources. 2011;2(1):10-18.

18. Xu SY, Liu JP, Huang X, Du LP, Shi FL, Dong R, et. al. UltrasonicMicrowave assisted extraction, characterization and biological activity of pectin from jackfruit peel. LWT-Food Science and Technology. 2018;90:577-582.

19. Fellah A, Anjukandi P, Waterland MR, Williams MAK. Determining the degree of methylesterification of pectin by ATR/FT-IR: Metodology optimisation and comparison with theoretical calculations. Carbohydrate Polymers. 2009;78:847-853.

20. Fasoli M, Dell'Anna R, Dal Santo S, Balestrini R, Sanson A, Pezzotti M, et al. Pectins, hemicelluloses and celluloses show specific dynamics in the internal and external surfaces of grape berry skin during ripening. Plant Cell Physiology. 2016;57(6):1332-1349. 